技術報文

\title{
メッシュ状布帛における糸密度及び糸交差角度の高精度計測手法
}

\author{
福井大学大学院工学研究科 小形憲弘・西門秀人・桜井哲真 \\ セーレン株式会社技術開発部門 高木進・城崎敦志

\section{High Precision Measurement Technique of Yarn Density And Yarn Crossover Angle in Mesh Cloth}

\author{
Norihiro Ogata ${ }^{* 1,{ }^{* 2}}$, Hideto Nishikado ${ }^{* 1}$, Tetsuma Sakurai ${ }^{* 1}$, Susumu Takagi ${ }^{* 2}$, and Atsushi Shirosaki ${ }^{* 2}$ \\ ${ }^{* 1}$ Graduate School of Engineering, University of Fukui, 3-9-1, Bunkyo, Fukuishi, Fukui 910-8507, Japan \\ ${ }^{* 2}$ Technical Development Section, SEIREN Co., Ltd., 1-10-1, Keya, Fukuishi, Fukui 918-8560, Japan
}

\begin{abstract}
Recently, the size of plasma display panels (PDPs) has been increasing, bringing about a need for a mesh cloth that can function as an electromagnetic shielding material for these new, larger PDPs. A cloth which serves as an electromagnetic wave shield for a PDP is known as a PDP-mesh.

The purpose of the present research was to propose a method of measuring yarn density and yarn crossover angle in mesh cloth. Although conventional trials of automatic measurement of yarn density in which one dimensional fast Fourier transform (FFT) was applied were carried out, it was difficult to verify the design value of a mesh cloth with a single trial. In the present method, a measured value is provided mathematically by connecting a texture feature of the mesh cloth with a characteristic of two dimensional FFT. PDP-mesh was used as an example of a measuring cloth. The measurement error of the yarn crossover angle with this method was found to be 0.1 degrees; additionally, we show that there is little measurement error of yarn density. Furthermore, the accuracy of the measurements obtained by the present method does not depend on the installation state of the measurement sample.
\end{abstract}

(Received 4 October, 2004; Accepted 24 January, 2005)

\section{1. まえがき}

近年, 大型化が進展しているプラズマディスプレイパネ ル (以下, PDP と表記) の電磁波シールド材として, メッ シュ状布帛に注目が集まっている（以下，PDPにおける電 磁波シールド用メッシュ状布帛を PDP メッシュと表記).

PDP メッシュは PDP の前面パネルに装着され, PDP の 発光素子に対して鑑賞者側に設置される. PDP の映像劣化 を抑えるために, PDP メッシュの構成糸は十分な細さが要 求される. PDP メッシュは, 糸の直径が $30 \mu \mathrm{m}$, 糸密度が たて糸, よこ糸共に 52.0 本 $/ \mathrm{cm}$ という緻密な織物を基材と している. PDP メッシュを配置した PDP 表面の拡大図を Fig. 1 に示す.

従来の PDP メッシュの出荷検査は, デンシメーターを 用いて糸密度を測定していた。.また, 糸交差角度は, 標準 測定試料が刻まれたフィルム上にPDP メッシュを設置し, これを投影させることで比較測定していた. どちらも肉眼 による目視評価であることからバラつきが大きく, 信頼性 に乏しかった.

糸密度の計測に関する研究として, 今岡らは 1 次元フー リエ変換を応用した自動測定[1]を試みているが, 糸の配列 方向については検討しておらず, 計測時における測定試料 の厳密な位置合わせが計測結果の精度を左右する.ここで,

「測定試料の厳密な位置合わせ」とは, 測定する矩形領域 の $x$ 軸または $y$ 軸と, 測定対象の糸の配列方向が成す角度 を指す。

本論文では, 測定試料の設置状態が計測結果に影響を及
ぼさない, 2 次元フーリエ変換を応用したデジタル的な数 值処理による糸密度及び糸交差角度の高精度計測手法を 提案する.

2. メッシュ状布帛における糸密度及び糸交差角度 の計測手法

\section{1 アルゴリズム}

PDP メッシュは，たて糸及びよこ糸が空間的に規則正し く配列されていて周期性を有する.このことから, PDP メ ッシュの空間的なテクスチャ特徵を抽出すれば, 糸密度及 び糸交差角度を数学的に求めることが可能であると考え た. PDP メッシュにおけるテクスチャ特徴の抽出アルゴリ ズムを以下に示す。

(1) PDPメッシュのデジタル画像をコンピュータに入 力

(2) 画像を高速フーリエ変換（以下, FFT : Fast Fourier Transformと表記）し，フーリエスペクトルを取得

(3) フーリエスペクトルのピークを抽出

(4) ピーク情報（周波数, 角度) をPDPメッシュのテ クスチャ特徵 (糸密度, 糸交差角度) に変換

\section{2 シミュレーション}

PDP メッシュにおけるテクスチャ特徴の抽出アルゴリズ ムに基づいて, PDP メッシュの画像をモデル化し，そのテ クスチャ特徵抽出のシミュレーションを行う。 


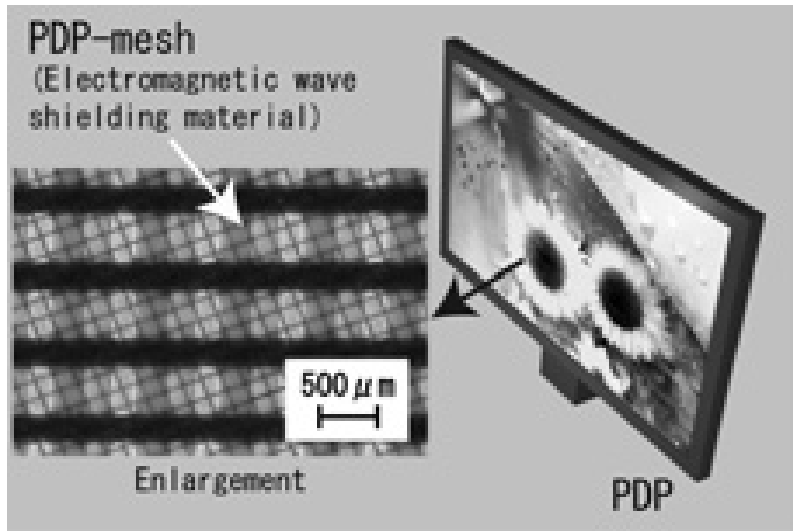

Fig. 1 Photomicrograph of the PDP-mesh.

\section{2. 1 PDP メッシュのデジタル画像をコンピュー タに入力}

PDP メッシュのモデルを線画で作成し，それを糸密度及 び糸交差角度が既知の標準測定試料とする。この標準測定 試料の糸密度及び糸交差角度の測定精度を評価すること で，本アルゴリズムの妥当性を検証した. Table 1 に PDP メッシュモデルの設計值を示す。なお，本論文において糸 密度は, $1 \mathrm{~cm}$ 当りの糸の本数で示す. Fig. 2 に PDPメッシ ユモデル画像を示す。

\section{2.2 画像をFFT し, フーリエスペクトルを取得}

画像は平面であることから, 水平方向と垂直方向の $2 つ$ の周波数成分を有する. また, 画像の場合, 周波数の配置 は, 中心が直流分, 右端が $f_{x} / 2$, 左端が $-f_{x} / 2$ という形式に することが常套とされている. 水平周波数を $u$, 垂直周波 数を $v$ とした際の 2 次元的な周波数成分の分布が (2 次元) フーリエスペクトルである.フーリエスペクトルと実際の 画像の関係を Fig. 3 に示す。縞模様が細かくなるにしたが って周波数が高くなる. また, 斜め方向の縞は, 図のよう に水平周波数と垂直周波数の両方の成分を有するプロッ トになる.フーリエスペクトルの計算には, 次式 (1) に 示す 2 次元の FFT[2]を使用する.

$$
\begin{aligned}
F(u, v) & =\frac{1}{\sqrt{M N}} \sum_{m=0}^{M-1} \sum_{n=0}^{N-1} G(m, n) \exp \left\{-2 \pi j\left(\frac{u m}{M}+\frac{v n}{N}\right)\right\} \\
\text { ここで, } & : \text { 画像の濃淡レベル } \\
m & : \text { 画像の } x \text { 軸座標 } \\
n & : \text { 画像の } y \text { 軸座標 } \\
M & : \text { 画像の } x \text { 軸画素数 } \\
N & : \text { 画像の } y \text { 軸画素数 } \\
F & : \text { フーリエスペクトル } \\
u & : \text { フーリエスペクトルの } x \text { 軸座標 } \\
v & : \text { フーリエスペクトルの } y \text { 軸座標 } \\
j & : \text { 虚数単位 }
\end{aligned}
$$

\begin{tabular}{|c|c|}
\hline Image size & $512 \times 512$ pixel \\
\hline PDP-mesh size & $2.54 \times 2.54 \mathrm{~cm}$ \\
\hline Yarn density of the warp : $D_{\text {warp }}$ & 25.2 number of yarns $/ \mathrm{cm}$ \\
\hline Yarn density of the weft $: D_{\text {weft }}$ & 50.4 number of yarns $/ \mathrm{cm}$ \\
\hline Angle of the warp $\quad: \theta_{\text {warp }}$ & $115.0^{\circ}$ \\
\hline Angle of the weft & $35.0^{\circ}$ \\
\hline Yarn crossover angle & $80.0^{\circ}$ \\
\hline
\end{tabular}

Fig. 2 に示す PDP メッシュモデル画像のフーリエスペク トルを Fig. 4 に示す．ここで，フーリエスペクトルを計算 する前に，スペクトルの先鋭度を向上させる目的で，画像 に空関数を施す. 空関数の効果については, 第 4 章で詳細 を述べる.

\section{2. 3 フーリエスペクトルのピークを抽出}

Fig. 4 のフーリエスペクトルにおいて, 上位 25 位（経験 的に設定）までのレベルの周波数座標を残し，残りをレベ ル 0 とする閾值処理を施す。閾值処理を式（2）に示す.
Table 1 Design value of the PDP-mesh model.

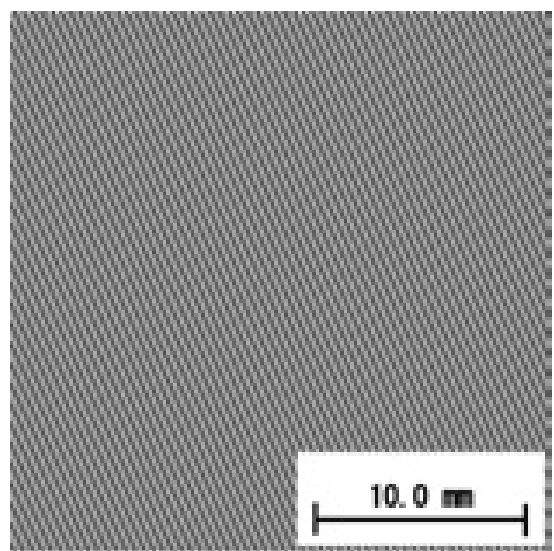

Fig. 2 Image of the PDP-mesh model.

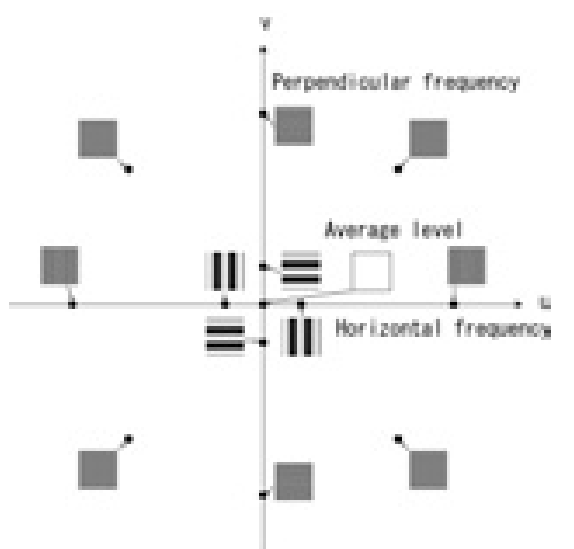

Fig. 3 Fourier spectrum and relation of an image.

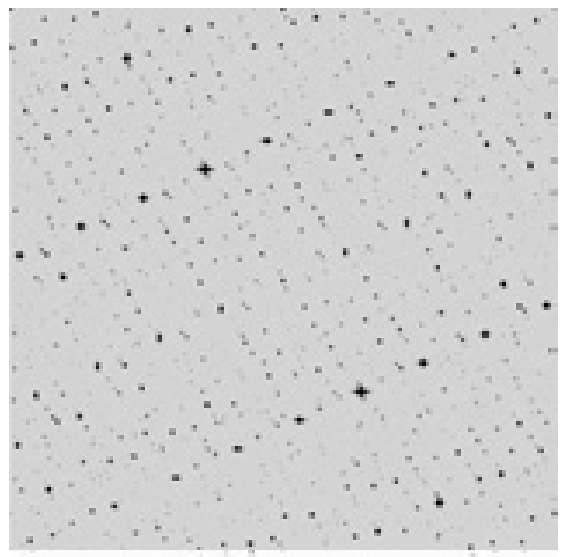

Fig. 4 Fourier spectrum of the PDP-mesh model.

$$
\begin{aligned}
& F^{\prime}(u, v)= \begin{cases}F(u, v) & F(u, v) \geq t \\
0 & F(u, v) \prec t\end{cases} \\
& \text { ここで, } \\
& F \quad: \text { 閾值処理前のフーリエスペクトルのレベル } \\
& F^{\prime} \quad: \text { 閾值処理後のフーリエスペクトルのレベル }
\end{aligned}
$$


$t \quad$ : 閾值

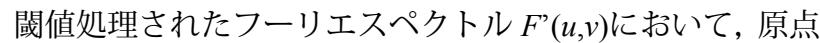
を中心に, 偏角 $\theta$ と動径 $r$ ( $r$ は空間周波数に対応) で表さ れる極座標 $F^{\prime}(\theta, r)$ に変換する. 次に, 各偏角におけるフー リエスペクトルのレベル総和を式（3）で算出する.

$$
\begin{aligned}
& F_{\text {total }}^{\prime}(\theta)=\sum_{r=1}^{r_{\text {max }}} F^{\prime}(\theta, r) \quad(\theta=0.0,0.1,0.2 \cdots, 180.0) \\
& \text { ここで, } \\
& F_{\text {total }}^{\prime}: \text { 偏角 } \theta \text { におけるレベル総和 } \\
& r_{\text {max }}: \text { 空間周波数 } r \text { に関して計測する最大值 }
\end{aligned}
$$

$r_{\text {max }}$ は空間周波数 $r$ の最大值であり, 画像サイズの半分 (こ こでは 512 pixel の半分：256）となる. また, $F^{\prime}(\theta, r)$ は原 点に対して対称であることから, $\theta$ の值域は $0.0^{\circ} \sim 180.0^{\circ}$ とする. 角度分解能は 0.1 ○とした. 各偏角 $\theta$ におけるレべ ル総和 $F{ }^{\prime}{ }_{\text {total }}(\theta)$ の分布を Fig. 5 に示す. 図より, レベル総 和の分布にはいくつかの鋭いピークが現れることがわか る. フーリエスペクトルの各ピークは, 1 つのデータ点で 形成されることが望ましいが, 実際には複数の点で形成さ れるため, 微小な幅を有するものとなる.ここで, フーリ エスペクトルの各ピークを形成するデータ点の集合体を クラスターとし，同図中にナンバリングを施す。

2. 2.4 ピーク情報（周波数, 角度）をPDPメッシュ のテクスチャ特徵（糸密度, 糸交差角度）に 変換

フーリエスペクトルのピーク抽出で得られた各クラス ターにおいて, それを形成する角度におけるレベル総和の 合計（クラスターの面積に相当）を次式（4）で算出する.

$$
\begin{aligned}
& F_{\text {cluster }}(k)=\sum_{i=\theta_{1}(k)}^{\theta_{2}(k)} F_{\text {total }}^{\prime}(i) \\
& \text { ここで, } \\
& F_{\text {cluster }}: \text { クラスターにおけるレベル総和の合計 } \\
& k \quad \text { : クラスター番号 } \\
& \theta_{1} \quad \text { : クラスターの始点の偏角 } \\
& \theta_{2} \text { : クラスターの終点の偏角 }
\end{aligned}
$$

算出結果を降順に並べ替え, 各クラスターにおける角度の 平均值 $\theta_{\text {mean }}$ を次式 (5) で算出する.

$$
\theta_{\text {mean }}(k)=\left\{\theta_{2}(k)+\theta_{1}(k)\right\} / 2
$$

Table 2 に結果をまとめて示す. Table 2 より, クラスタ 一(5)及びクラスター(2)におけるクラスター平均值 $\theta_{\text {mean }}=$ 125.0 ○とクラスター平均值 $\theta_{\text {mean }}=25.0$ ○の方向にレベル総 和の合計 $F_{\text {cluster }}(k)$ が大きいことがわかる. $\theta$ 方向において, レベル総和の合計 $F_{\text {cluster }}(k)$ が大きいということは, その方 向における空間周波数成分が大きいということであり, 画 像上で, その方向における濃淡変化が大きいことを示唆し ている. PDPメッシュのたて糸及びよこ糸方向に対して直 角を成す方向は, 糸部分と空隙部分の繰り返しの頻度が最 も大きい部分であり, これが画像の大きな濃淡変化に対応 する. 上記理由から，レベル総和の合計 $F_{\text {cluster }}(k)$ における 上位 2 位までのクラスターにおける偏角の平均值と直角を 成す角度を, たて糸方向及びよこ糸方向に対応させること が可能であると考えられる. Table 2 より, レベル総和の合 計における偏角の平均值 $\theta_{\text {mean }}$ の上位 1 位を $\theta_{\text {sum } 1}$ とし, 2 位の偏角の平均值を $\theta_{\text {sum } 2}$ とし, たて糸の角度及びよこ糸 の角度を次式（6）で算出する.

$$
\begin{gathered}
\theta_{\text {sum } 1} \geq \theta_{\text {sum } 2} \text { の場合 } \\
\theta_{\text {warp }}=\theta_{\text {sum } 2}+90 \\
\theta_{\text {weft }}=\theta_{\text {sum } 1}-90 \\
\theta_{\text {sum } 1} \prec \theta_{\text {sum } 2} \text { の場合 } \\
\theta_{\text {warp }}=\theta_{\text {sum } 1}+90 \\
\theta_{\text {weft }}=\theta_{\text {sum } 2}-90 \\
\text { ここで, } \\
\theta_{\text {warp }}: \text { たて糸の角度 } \\
\theta_{\text {weft }}: \text { よこ糸の角度 }
\end{gathered}
$$

式（6）より,たて糸の角度 $\theta_{\text {warp }}$ は $115^{\circ}$, よこ糸の角度 $\theta_{\text {weft }}$ は 35 ○となる.なお, 糸の交差角度 $\theta_{\text {cross }}$ は次式（7） で計算する.

$$
\begin{aligned}
\theta_{\text {cross }} & =\left|\theta_{\text {weft }}-\theta_{\text {warp }}\right| \\
\theta_{\text {cross }} & \succ 90 \text { の場合 } \\
\theta_{\text {cross }} & =180-\left|\theta_{\text {weft }}-\theta_{\text {warp }}\right|
\end{aligned}
$$

閾值処理されたフーリエスペクトル $F^{\prime}(u, v)$ と, たて糸の角 度 $\theta_{\text {warp }}$, よこ糸の角度 $\theta_{\text {weft }}$ 及び糸の交差角度 $\theta_{\text {cross }}$ の対応 を Fig. 6 に示す. ここで, フーリエスペクトルにおけるピ ーク位置は, 視認性のために膨張処理を施した[3].

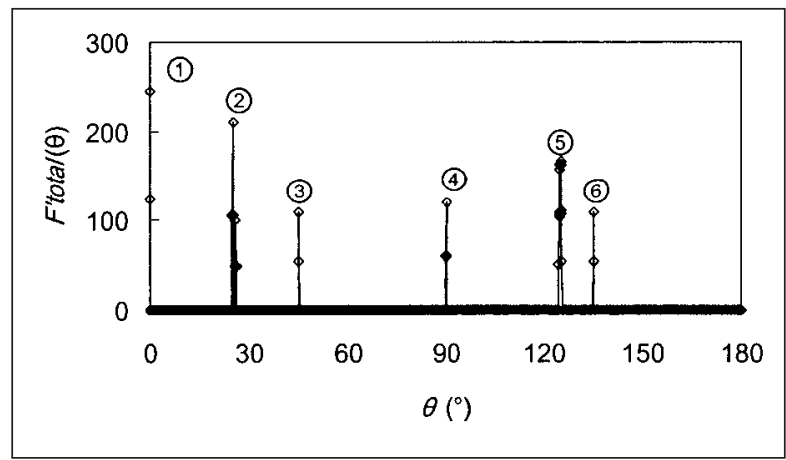

Fig. 5 Distribution of total level (1)-(6): Cluster number).

Table 2 Calculation results.

\begin{tabular}{ccc}
\hline Cluster $k$ & $F_{\text {cluster }}(k)$ & $\theta_{\text {mean }}(k)^{\circ}$ \\
\hline 5 & 1292.5 & 125.0 \\
\hline 2 & 421.5 & 25.0 \\
\hline 1 & 368.9 & 0.1 \\
\hline 4 & 236.8 & 90.0 \\
\hline 3 & 218.6 & 45.0 \\
\hline 6 & 218.6 & 135.0 \\
\hline
\end{tabular}

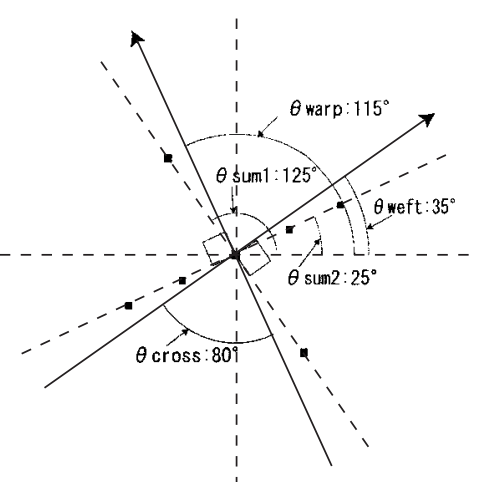

Fig. 6 Correspondence between the peak information and the texture feature of the PDP-mesh model. 
次に, 糸密度の算出手順を示す.たて糸方向に対して直 角を成す角度, よこ糸方向に対して直角を成す角度がそれ ぞれ既知であることから，その方向における空間周波数 $r$ に関するフーリエスペクトルのレベル総和 $F{ }^{\prime}{ }_{\text {total }}(r)$ 分布を 算出すればよい. 用いた計算式を式（8）に示す.

$$
F_{\text {total }}^{\prime}(r)=\sum_{\theta^{\prime}=\theta-\Delta \theta}^{\theta+\Delta \theta} F^{\prime}\left(\theta^{\prime}, r\right)
$$

ここで, $\Delta \theta$ は, $\theta$ に関する計測幅であり, $\Delta \theta=0.2$ とし た. ある空間周波数 $r$ において, レベル総和 $F_{\text {total }}{ }^{\prime}(r)$ が大 きいということは，画像上において，その空間周波数 $r$ に 相当する規則的な濃淡の繰返しが, 頻繁に現れていること を示唆している. たて糸方向に対して直角を成す角度であ る 25 ○方向における計算結果を Fig. 7 に示す. Fig. 7 より, ピークが複数存在し, 複数のクラスターを形成しているこ とがわかる. 各クラスターにおける空間周波数 $r$ の平均值 $r_{\text {mean }}$ を次式 (9) で算出する.

$$
\begin{array}{ll}
r_{\text {mean }}(k)= & \left\{r_{2}(k)+r_{1}(k)\right\} / 2 \\
\text { ここで, } & \\
k & : \text { クラスター番号 } \\
r_{1} & : \text { クラスターの始点の空間周波数 } \\
r_{2} & : \text { クラスターの終点の空間周波数 }
\end{array}
$$

結果を Table 3 に示す. PDP メッシュのモデル画像は, 糸が有るか無いかの離散信号であり, 離散信号を FFT 処理 した場合, 得られるフーリエスペクトルは倍周波数の位置 にピークが観測される. したがって, 同一角度に複数のピ ークが存在する.ここで, 同一角度における最も小さいク ラスターである空間周波数 $r$ の平均值 $r_{\text {mean }}=64$ が求めるべ き值であり，これがたて糸における糸の本数に対応する.

次に, よこ糸方向に対して直角を成す角度である $125^{\circ}$ 方向においても上記と同様の処理を施す. 結果を Fig. 8 と Table 4 に示す. Table 4 より，クラスター11における空間 周波数 $r$ の平均值 $r_{\text {mean }}=128$ が求めるべき值であり, これ がよこ糸における糸の本数に対応する. 本論文において糸 密度は, $1 \mathrm{~cm}$ 当りの糸の本数で示すので, 次式 (10) で変 換する.

$$
\begin{aligned}
& \text { たて糸密度の場合 } \\
& D_{\text {warp }}=r_{\text {mean }} / S \\
& \text { よこ糸密度の場合 } \\
& D_{\text {weft }}=r_{\text {mean }} / S \\
& \text { ここで, } \\
& D_{\text {warp }}: \text { たて糸密度 (number of yarns } / \mathrm{cm} \text { ) } \\
& D_{\text {weft }}: \text { よこ糸密度 (number of yarns } / \mathrm{cm} \text { ) } \\
& S \quad: \text { PDPメッシュのサイズ }(\mathrm{cm})
\end{aligned}
$$

上記結果を Table 5 にまとめる. Table 5 の計算值と Table 1 の PDP メッシュモデルの設計值とを比較すれば明らかな ように, 本提案手法により高精度な計測が達成されたと言 える. また, PDP メッシュのたて糸及びよこ糸が画像に対 して傾きを有する場合, 糸交差角度が直角でない場合, た て糸とよこ糸の糸密度がそれぞれ異なる場合でも, 正確な 測定が可能であることがわかる.

Table 3 Calculation results.

\begin{tabular}{cc}
\hline Cluster $k$ & $r_{\text {mean }}$ \\
\hline 1 & 64.0 \\
\hline 2 & 128.0 \\
\hline
\end{tabular}

Table 4 Calculation results.

\begin{tabular}{cc}
\hline Cluster $k$ & $r_{\text {mean }}$ \\
\hline 1 & 128.0 \\
\hline
\end{tabular}

Table 5 Calculation results.

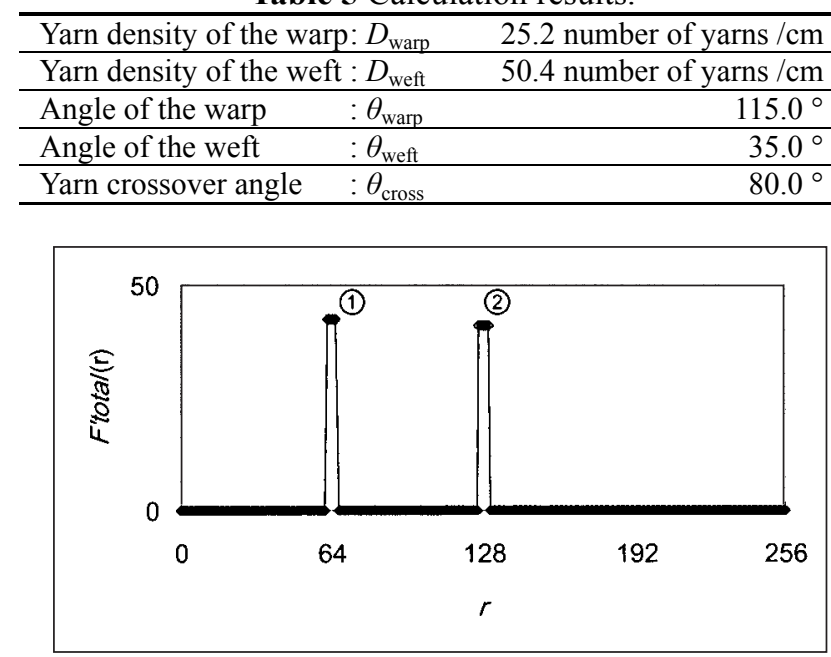

Fig. 7 Distribution of total level in $25^{\circ}$ (1), (2): Cluster).

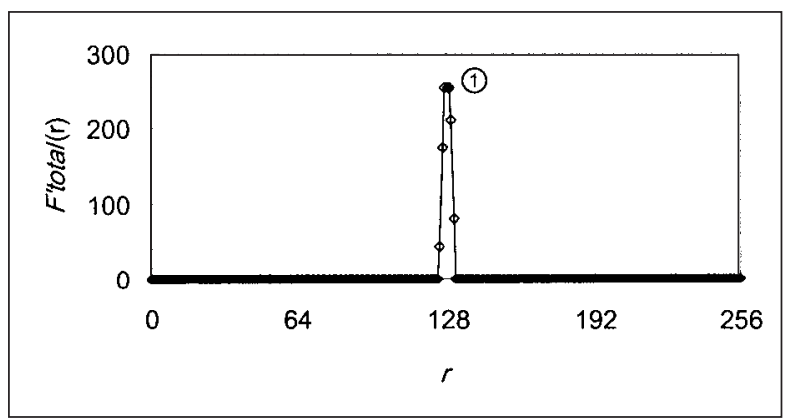

Fig. 8 Distribution of total level in $125^{\circ}$ (1): Cluster).

\section{PDP メッシュにおける手法の評価}

\section{1 検査装置}

Fig. 9 に検査装置の構成図を示す。測定光学系は, 45 。 方向入射, 0 方向受光である. 白色板の上に計測対象であ る PDP メッシュを設置し, アクリル板でそれを挟む. こ こで,アクリル板とカメラレンズとの距離は $15 \mathrm{~cm}$ であり, 45 方向より, 拡散照明された PDPメッシュの画像を 0 。 方向に設置された CCD カメラで取得する仕組みとした. CCD カメラには, モノクロ冷却 CCD カメラを採用した. 有効画素は $512 \times 512$ pixel である. また, CCD カメラの撮 影位置の校正及び画素と実サイズの測定には, カメラ校正 用グリッドを使用した。 カメラ校正用グリッドのサイズが $5.1 \times 5.1 \mathrm{~cm}$ であることから, 本検査装置の検査対象領域の 最大サイズは $5.1 \times 5.1 \mathrm{~cm}$ となる. 照明機器には, 標準の光 D65 の常用光源である人工太陽照明灯に, D65 近似フィル タと拡散照明フィルタを装着したものを用いる.

\section{2 実 験}

実際の PDP メッシュを対象とした測定評価を行った。 方法は, 2.2 節のシミュレーションと同様である. Table 6 に計測対象とした PDP メッシュの設計值を示す. Fig. 10 に PDPメッシュの撮像画像を示す.また, 測定結果を Table 7 に示す. 


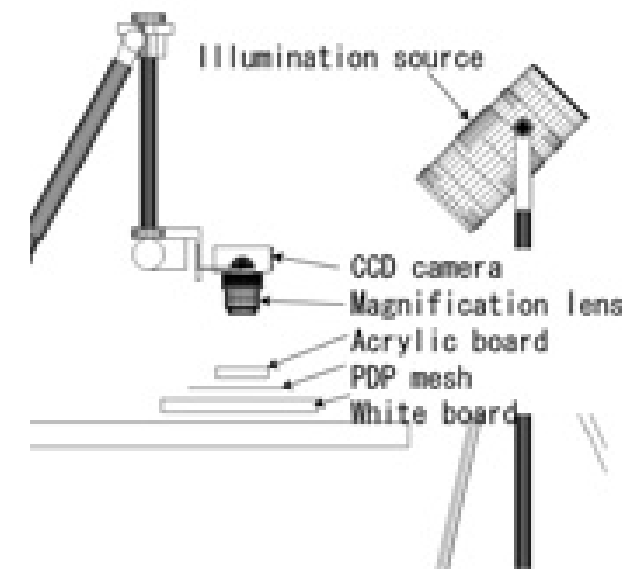

Fig. 9 Configuration of the inspection system.

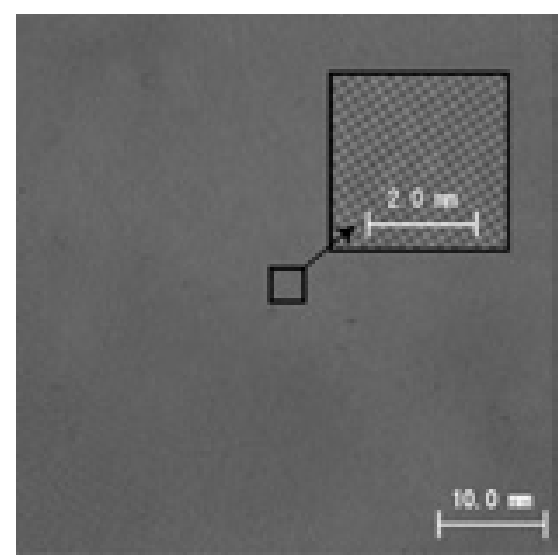

Fig. 10 Original image of the PDP-mesh.

Table 6 Design value of the PDP-mesh model.

\begin{tabular}{lr}
\hline PDP-mesh size & $5.10 \times 5.10 \mathrm{~cm}$ \\
\hline Yarn density of the warp: $D_{\text {warp }}$ & 52.0 number of yarns $/ \mathrm{cm}$ \\
\hline Yarn density of the weft : $D_{\text {weft }}$ & 52.0 number of yarns $/ \mathrm{cm}$ \\
\hline Yarn crossover angle $: \theta_{\text {cross }}$ & $90.0^{\circ}$ \\
\hline
\end{tabular}

Table 7 Calculation results.

\begin{tabular}{|c|c|c|}
\hline Yarn density of the w & $0: D_{\text {warp }}$ & 52.0 number of yarns $/ \mathrm{cm}$ \\
\hline Yarn density of the w & $: D_{\text {weft }}$ & 52.0 number of yarns $/ \mathrm{cm}$ \\
\hline Angle of the warp & $: \theta_{\text {warp }}$ & $123.9^{\circ}$ \\
\hline Angle of the weft & $: \theta_{\text {weft }}$ & $33.8^{\circ}$ \\
\hline Yarn crossover angle & $: \theta_{\text {cross }}$ & $89.9^{\circ}$ \\
\hline
\end{tabular}

\section{4. 結果及び考察}

Table 6 と Table 7 とを比較することにより，糸密度は設 計值通りに製造されていることがわかる. また，糸交差角 度は 89.9 ○であり，設計值に対して $0.1 \circ$ 差があるが，本 検査装置の角度分解能を 0.1 ○としたとから, 89.9〜 $90.1^{\circ}$ を許容值の最小值とせざるを得ない. その範疇においては, 設計值の許容内であると言える。また，よこ糸を基準とす れば, PDP メッシュは CCD カメラに対して 33.8 のの傾きを 有して白板上に設置されたことがわかる，このことは，実 際のオンライン検査において, 測定試料の厳密な位置合わ せを必要とせずに, 正確な測定值が得られることを示唆し ている。

次に, 系密度変化及び糸交差角度変化に対する測定精度 への影響について述べる. 糸密度と糸交差角度における測 定誤差を次式（11）で定義する.

$$
\left.\begin{array}{l}
E_{\mathrm{D}}=\left|D_{\text {target }}-D_{\text {standard }}\right| / D_{\max } \times 100 \\
E_{\theta}=\left|\theta_{\text {target }}-\theta_{\text {standard }}\right| / \theta_{\max } \times 100
\end{array}\right\}
$$

糸密度変化に対する測定精度への影響は, PDP メッシュ モデルにおいて, 糸交差角度を 90 ○に固定し, 糸密度を 1.6 〜03.1 本/cm の間で変化させて測定試験を行った. Fig. 11 に結果を示す. 糸交差角度変化に対する測定精度への影響 は, 同様に PDP メッシュモデルにおいて, 糸密度を 50.4 本 $/ \mathrm{cm}$ に固定し，糸交差角度を 10９0。変化させて測定試 験を行った. Fig. 12 に結果を示す. Fig. 11 及び Fig. 12 よ り, 糸密度変化及び糸交差角度変化による測定精度への影 響は，無視できる程度であることがわかる.

次に, 測定再現性について述べる. 糸密度が異なる (39.4 〜131.1 本 $/ \mathrm{cm}) 9$ 種類の実際の PDP メッシュを用意し，そ れぞれ 30 回測定した際の測定再現性について調べた。測 定再現性を次式（12）で定義する.

$$
\begin{aligned}
& \operatorname{AveE}_{\mathrm{D}}=\sum_{i=0}^{n} E_{\mathrm{D}}(i) / n \\
& \operatorname{AveE}_{\theta}=\sum_{i=0}^{n} E_{\theta}(i) / n
\end{aligned}
$$

ここで,

$A v e E_{\mathrm{D}} \quad$ : 糸密度の測定再現性

$A v e E_{\theta} \quad$ : 糸交差角度の測定再現性

$n$ : 測定回数

測定毎に PDP メッシュを設置し直し，CCD カメラに対す る角度調整は行っていない. 結果を Fig. 13 に示す. ここ で, 図中の PDP メッシュの識別を糸密度で示す。試験結 果は, 糸密度に関する測定再現性の平均值は $0.06 \%$, 糸交 差角度に関する測定再現性の平均值は $0.05 \%$ であり，誤差 の少ない高い測定再現性が得られた。

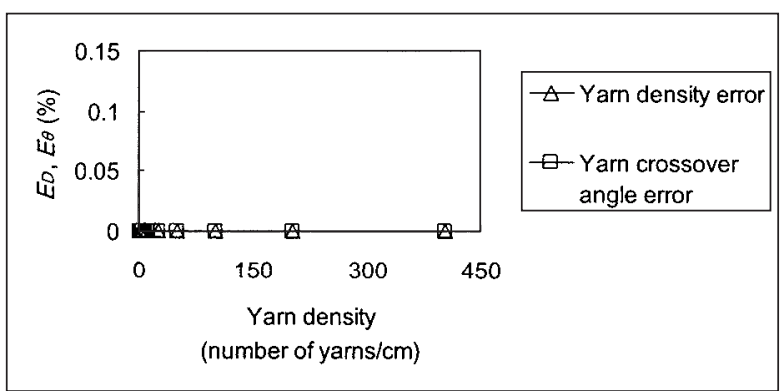

Fig. 11 Measurement accuracy (Yarn density). 


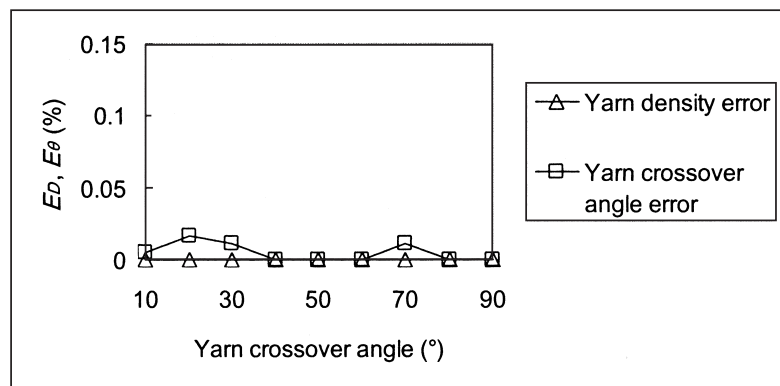

Fig. 12 Measurement accuracy (Yarn crossover angle).

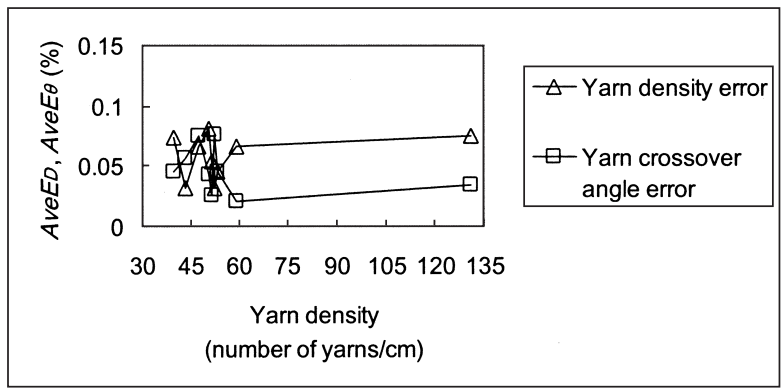

Fig. 13 Measurement repeatability.

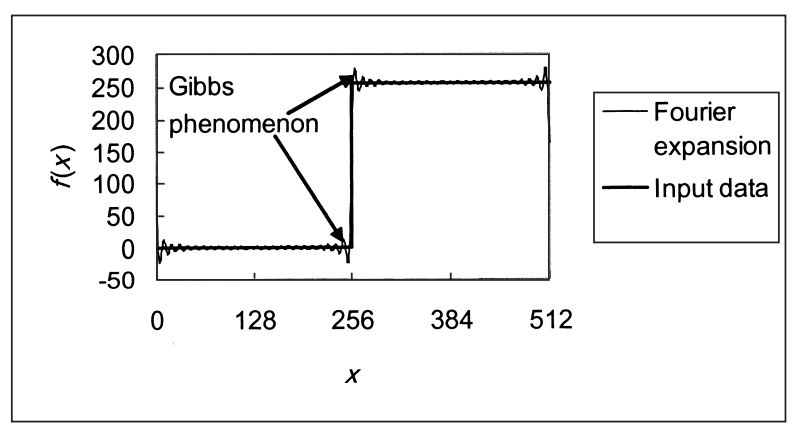

Fig. 14 Gibbs phenomenon.

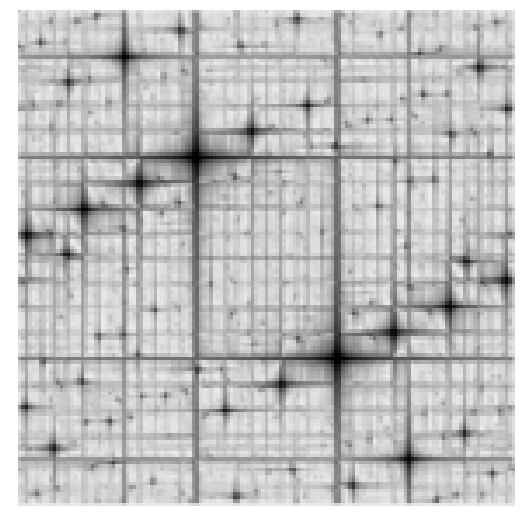

Fig. 15 Normal input image.

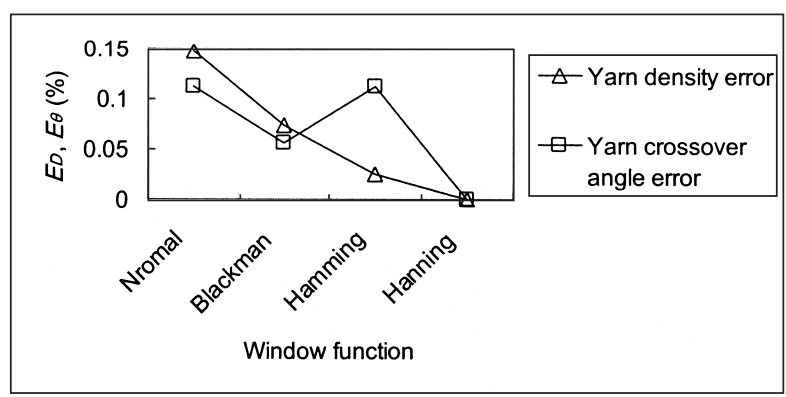

Fig. 16 Effect of a window function.
Table 8 Specifications of $\mathrm{PC}$ and calculation time.

\begin{tabular}{lr}
\hline CPU & Pentium III $800 \mathrm{MHz}$ \\
\hline RAM & $256 \mathrm{MB}$ \\
\hline Calculation time & $1613 \mathrm{msec}$ \\
\hline
\end{tabular}

次に, 空関数の効果について述べる. 入力される画像は, その両端において不連続面が生じる. 例として $x=255$ で 不連続面が存在する周期が 512 の方形波を Fig. 14 に示す. 不連続点の近傍では，大きなリップル（行き過ぎ量）が発 生している事がわかる.この現象はギブス現象と呼ばれ, 方形波のように不連続点を持つ周期関数をフーリエ級数 で表した場合に生じる現象であり, 測定精度に悪影響を及 ぼす. ギブス現象を軽減する方法として, 画像の打ち切り 幅の両端で次第に小さな值になるように空関数を乗じる 方法がある[4]. 本計測手法では, 空関数として, ハニング 空関数を採用した. 式（13）にハニング空関数を示す.

$$
W(m)=0.5-0.5 \cos (2 \pi m / N)
$$

空関数を施さない状態で, Fig. 1 に示した PDP メッシュモ デル画像に FFT を施したフーリエスペクトルを Fig. 15 に 示す. Fig. 4 のフーリエスペクトルは, ハニング空関数が 施してある. Fig. 4 と Fig. 15 を比較すれば, 空関数を施し たフーリエスペクトルは, より先鋭度の高いピークが得ら れていることがわかる. Fig. 16 に空関数の効果を示す. 八 ニング空関数の他に, ハミング空関数及びブラックマン空 関数でも効果を確認したが, ハニング空関数が最も効果的 であった。

次に, 実験に使用した PC のスペックと計算時間を Table 8 に示す. 通常の PC スペックのレベルで, 約 1.6 秒という 実用的な範囲での計算時間を実現することができた. 測定 精度と測定時間が, PDP メッシュの糸密度及び糸交差角度 の検査工程において十分実用的な範囲にあることから，本 検査装置の工場検査ラインへの組込みは可能であると考 える。

\section{5. 結 論}

デジタル画像処理による PDP メッシュの糸密度及び糸 交差角度の計測手法を提案した. この手法では, 2 次元 FFT と空関数を生かしたアルゴリズムに特徵があり, 試作装置 により, 大口径化が進むプラズマディスプレイパネルの電 磁波シールド材として用いられる, メッシュ状布帛の糸密 度及び糸交差角度の高精度で安定な測定が可能であるこ とを示した。

\section{謝 辞}

本測定手法の確立にあたり, 有益な助言を頂いた福井大 学工学部の吉田俊之教授, 同じく福井大学工学部の山口新 司教授に深く感謝致します.

\section{参 考 文 献}

1. Haruki Imaoka, Shigeru Inui, Haruo Niwaya, and Atsuo Shibuya, "Trial on Automatic Measurement of the Density", Sen'I Gakkaishi, 32, 1, pp. 32-39 (1988)

2. Jae S. Lim and Alan V. Oppenheim, "Advanced Topics in Signal Processing", Prentice Hall Signal Processing Series, pp. 385-389 (1988), ISBN 0-13-013129-6

3. 八木伸行, “C 言語で学ぶ実践画像処理”, オーム社, pp.65-69, ISBN 4-274-07703-9

4. Andreas Antoniou, "Digital Filters : Analysis and Design", McGraw-Hill Book, pp. 226-253(1979), ISBN 0-07002117-1 